\title{
Kepadatan Bivalvia di Kawasan Estuaria Mangrove Perpat dan Bunting Belinyu, Bangka
}

\author{
Nursah Putri ${ }^{*}$, Budi Afriyansyah1, Ristiyanti Marsetiyowati Marwoto² \\ 'Program Studi Biologi, Fakultas Pertanian, Perikanan dan Biologi, Universitas Bangka Belitung \\ Jl. Kampus Peradaban, Balunijuk, Merawang, Bangka Belitung 33172 indonesia \\ 2Bidang Zoologi, Pusat Penelitian Biologi, Lembaga llmu Pengetahuan Indonesia \\ Jl. Raya Jakarta-Bogor, Km. 46, Cibinong, Jawa Barat 16911 Indonesia \\ Email: nursahputri.26@gmail.com
}

\section{Abstract \\ Density of Bivalves in the Mangrove Estuary Area of Perpat and Bunting Belinyu, Bangka}

The bivalve density index can be used as an indicator of water quality. The purpose of this study was to determine the density of bivalves in the estuaria areas of Mangrove Perpat and Bunting Belinyu, Bangka. The method used was purposive sampling. Observations were made at six stations with 3 stations in each consisting of 4 substations. Sampling was done by using a plot size of $1 \times 1 \mathrm{~m}$ as many as 5 plots. The ecological index analysis includes: species density, species diversity, uniformity and dominance. The results showed that there were 12 species of bivalves belonging to nine families. The bivalve species were dominated by Geloina expansa with a total density of 3.5 ind / m2, while for mangroves, Rhizophora apiculata was the dominant species. The results of data analysis showed that the diversity of bivalves in the Perpat River mangrove was moderate, ranging from 0.614 to 1.675 while the Bunting Mangrove areas was low, ranging from 0 - 0.952. Environmental factors that most influence the density of bivalves in this study are water temperature and water $\mathrm{pH}$. Meanwhile, the relationship between mangrove density and bivalve density in this study showed a very weak relationship.

Keywords : bivalves, mangroves, Perpat, Bunting, Belinyu

\begin{abstract}
Abstrak
Indeks kepadatan bivalvia dapat digunakan sebagai indikator kualitas perairan. Tujuan penelitian ini untuk mengetahui kepadatan bivalvia di kawasan estuaria Mangrove Perpat dan Bunting Belinyu, Bangka. Metode yang digunakan adalah purposive sampling. Pengamatan dilakukan pada enam stasiun dengan masing-masing lokasi sebanyak 3 stasiun yang terdiri dari 4 substasiun. Pengambilan sampel dilakukan dengan menggunakan plot ukuran $1 \times 1 \mathrm{~m}$ sebanyak 5 plot. Analisis indeks ekologi meliputi: kepadatan jenis, keanekaragaman jenis, keseragaman dan dominansi. Hasil penelitian menunjukkan bahwa terdapat 12 spesies bivalvia yang tergolong dalam sembilan famili. Spesies bivalvia didominasi Geloina expansa dengan total kepadatan $3,5 \mathrm{ind} / \mathrm{m}^{2}$ sedangkan untuk tumbuhan mangrovenya didominasi oleh Rhizophora apiculata. Hasil analisis data menunjukkan bahwa keanekaragaman jenis bivalvia pada mangrove Sungai Perpat tergolong sedang, berkisar 0,614-1,675 sedangkan pada area Mangrove Bunting tergolong rendah, berkisar 0-0,952. Faktor lingkungan yang paling berpengaruh terhadap kepadatan bivalvia pada penelitian ini adalah suhu air dan $\mathrm{pH}$ air. Sedangkan hubungan antara kerapatan jenis mangrove terhadap kepadatan bivalvia pada penelitian ini menunjukkan hubungan sangat lemah.
\end{abstract}

Kata kunci : bivalvia, mangrove, Perpat, Bunting, Belinyu 


\section{PENDAHULUAN}

Bangka Belitung adalah provinsi dengan potensi sumber daya perairan yang sangat tinggi salah satunya Kecamatan Belinyu. Belinyu memiliki luas $746,50 \mathrm{~km}^{2}$ dengan potensi sumberdaya perairan yang terdapat pada kawasan estuari mangrove Perpat dan Bunting yang berada di Kelurahan Air Jukung. Berdasarkan hasil wawancara yang dilakukan dengan anggota Komunitas Sungai Bunting Lestari (SBL), luas total mangrove di kawasan Perpat \pm 40 ha dengan karakteristik lokasi antara lain: adanya ekowisata, aktifitas nelayan, dan penambangan timah sedangkan luas total mangrove di kawasan Bunting \pm 30 ha dengan karakteristik lokasi antara lain: adanya ekowisata, aktifitas nelayan, pembuatan kapal, pencucian kapal, penambangan dan adanya penggalian sungai untuk lalu lintas kapal besar dan banyak mangrove yang dialihfungsikan untuk tempat pertambakan.

Mangrove adalah salah satu tumbuhan dikotil yang hidup di daerah pantai, beriklim tropis, substrat berlumpur, dan lahan terhadap salinitas (Chandra et al., 2011). Fungsi ekologis ekosistem mangrove antara lain: pelindung pantai dari serangan angin, arus dan ombak dari laut, habitat, tempat mencari makan, tempat asuhan dan pembesaran, dan tempat pemijahan bagi biota perairan (Samir dan Romy, 2016). Mangrove sangat mempengaruhi keanekaragaman makrofauna yang berasosiasi di dalamnya, kepiting dan moluska merupakan makrofauna paling dominan (Dewiyanti dan Sofyatuddin 2011). Salah satu makrofauna yang termasuk ke dalam Filum Moluska adalah bivalvia dimana memiliki kemampuan adaptasi yang tinggi terhadap tempat dan cuaca sehingga memberi pengaruh terhadap keberadaannya di suatu daerah (Triwiyanto et al., 2015). Bivalvia adalah biota yang biasa hidup menetap di dalam substrat dasar yang relatif lama sehingga biasa digunakan sebagai bioindikator untuk menduga kualitas perairan (Pakaya et al., 2017). Bivalvia dapat digunakan sebagai bioindikator kualitas perairan karena bivalvia menghabiskan seluruh hidupnya di kawasan tersebut sehingga apabila terjadi pecemaran lingkungan maka tubuhnya akan terpapar oleh bahan pencemar dan terjadi akumulasi. Jika ada bahan tercemar yang masuk di tubuh spesies tersebut, tubuh dari spesies yang tidak toleran tidak dapat bertahan hidup, dengan demikian keberadaanya dapat digunakan sebagai bioindikator (Wahyuni ef al., 2017).

Distribusi bivalvia pada ekosistem mangrove dipengaruhi oleh beberapa faktor diantaranya bahan makanan seperti ketersediaan fitoplankton, zooplankton, zat organik tersuspensi dan makhluk hidup lain di lingkunganya (Natsir dan Asyik 2019). Sedangkan faktor fisik kimia yang dapat mempengaruhi keberadaan bivalvia diantaranya suhu, $\mathrm{pH}$, salinitas dan DO. Kawasan mangrove yang dialihfungsikan sebagai ekowisata, kawasan penambangan timah dan adanya aktifitas nelayan diduga akan mempengaruhi kondisi mangrove dan biota di dalamnya, termasuk bivalvia. Selain itu banyak masyarakat sekitar yang menangkap dan memanfaatkan bivalvia baik untuk konsumsi sendiri maupun untuk dijual. Masyarakat sekitar hanya mengetahui manfaat bivalvia sebatas untuk konsumsi saja. Penelitian yang telah dilakukan mengenai kepadatan bivalvia dimana ditemukan empat spesies bivalvia yaitu Anadara sp., Pharus sp., Geloina sp. dan Perna viridis dengan kepadatan tertinggi spesies Pharus sp. (Suwondo et al., 2012). Penelitian yang dilakukan oleh Wahyuni et al. (2017) menunjukkan bahwa kawasan Pesisir Pulau Tunda termasuk kedalam kategori 'Tercemar Sangat Ringan' dimana berdasarkan nilai indeks keanekaragaman moluska yang berkisar antara 3,1356-3,3314. Keberadaan bivalvia dapat dijadikan sebagai bioindikator suatu lingkungan. Tujuan penelitian ini untuk mengetahui kepadatan bivalvia di kawasan estuaria Mangrove Perpat dan Bunting Belinyu, Bangka.

\section{MATERI DAN METODE}

Penelitian ini dilaksanakan pada bulan Maret hingga Mei 2020, berlokasi di kawasan Mangrove Perpat dan Bunting, Kecamatan Belinyu, Bangka. Peta Lokasi Penelitian dapat dilihat pada Gambar 1. Metode yang digunakan yaitu metode survey dan penentuan stasiun pengamatan menggunakan 
teknik purposive sampling. Titik stasiun ditentukan dengan menggunakan GPS. Setiap lokasi penelitian dibuat 3 stasiun, stasiun 1, 2 dan 3 (mangrove perpat), stasiun 4, 5 dan 6 (mangrove bunting) dengan ukuran setiap stasiun $20 \mathrm{~m} \times 20 \mathrm{~m}$ dengan jarak antar stasiun $\pm 20 \mathrm{~m}$, di dalam stasiun terdapat 4 sub stasiun dengan ukuran $10 \mathrm{~m} \times 10 \mathrm{~m}$ dengan plot transek di dalamnya dengan ukuran $1 \mathrm{~m} \times 1 \mathrm{~m}$ sebanyak 5 plot untuk pengambilan sampel bivalvia. Waktu pengambilan sampel dilakukan saat pasang surut terendah berdasarkan acuan tabel prediksi pasang surut (BPBD Babel, 2020).

Pengambilan sampel dilakukan pada bivalvia yang masih hidup dengan cara melihat lubang yang terbentuk pada substrat serta serta menggali substrat sedalam $\pm 20 \mathrm{~cm}$ menggunakan sekop kecil kemudian substrat pada tiap plot disaring dengan saringan plastik. Bivalvia yang didapat dikumpulkan dan dibersihkan, setelah itu dimasukkan ke dalam plastik sampel yang berisi alkohol $70 \%$ lalu diberi label. Sampel dibawa ke Laboratorium Biologi Universitas Bangka Belitung untuk diidentifikasi berdasarkan morfologi, warna dan corak cangkang, serta tipe gigi engsel dengan acuan buku "Recent dan Fossil Indonesian Shells" (Dharma 2005) dan buku "Compendium of Seashells" (Abbott dan Dance 2000). Selanjutnya dilakukan pengukuran morfometri yang meliputi panjang dan lebar cangkang lalu dijadikan spesimen dengan cara dipindahkan ke dalam wadah koleksi dan diberi alkohol $70 \%$ hingga sampel tersebut terendam.

Pengambilan data mangrove menggunakan metode Transect Line Plot (TLP). Data dicuplik menggunakan petak yang dibuat di dalam stasiun pengambilan sampel bivalvia dengan ukuran $10 \mathrm{~m} \times 10 \mathrm{~m}$ untuk diambil mangrove dengan kelompok pohon (tinggi $>1 \mathrm{~m}$ dan diameter $>10 \mathrm{~cm}$ ), ukuran plot $5 \mathrm{~m} \times 5 \mathrm{~m}$ untuk pancang (diameter 2-10 $\mathrm{cm}$ ), ukuran $1 \mathrm{~m} \times 1 \mathrm{~m}$ untuk semai (diameter < $2 \mathrm{~cm}$ ) (Mughofar et al., 2018). Mangrove diidentifikasi dengan menggunakan buku Panduan Pengenalan Mangrove di Indonesia (Noor et al. 2006). Pengukuran parameter lingkungan (kualitas air) meliputi pengukuran suhu, pH, DO, dan salinitas. Pengukuran suhu yaitu menggunakan thermometer. Pengukuran $\mathrm{pH}$ menggunakan $\mathrm{pH}$ meter, DO menggunakan DO meter dan Salinitas menggunakan refraktometer. Sedangkan penentuan fraksi tanah dengan menggunakan metode ayakan kering dan pemipetan.

Hasil pengambilan data di lapangan kemudian dianalisis sebagai berikut 1) Kepadatan spesies, 2) Indeks keanekaragaman, 3) Indeks keseragaman, 4) Indeks dominansi, 5) kerapatan dan indeks nilai penting mangrove, 6) tipe subsrat dan 7) analisis hubungan mangrove, parameter lingkungan dengan kepadatan bivalvia.

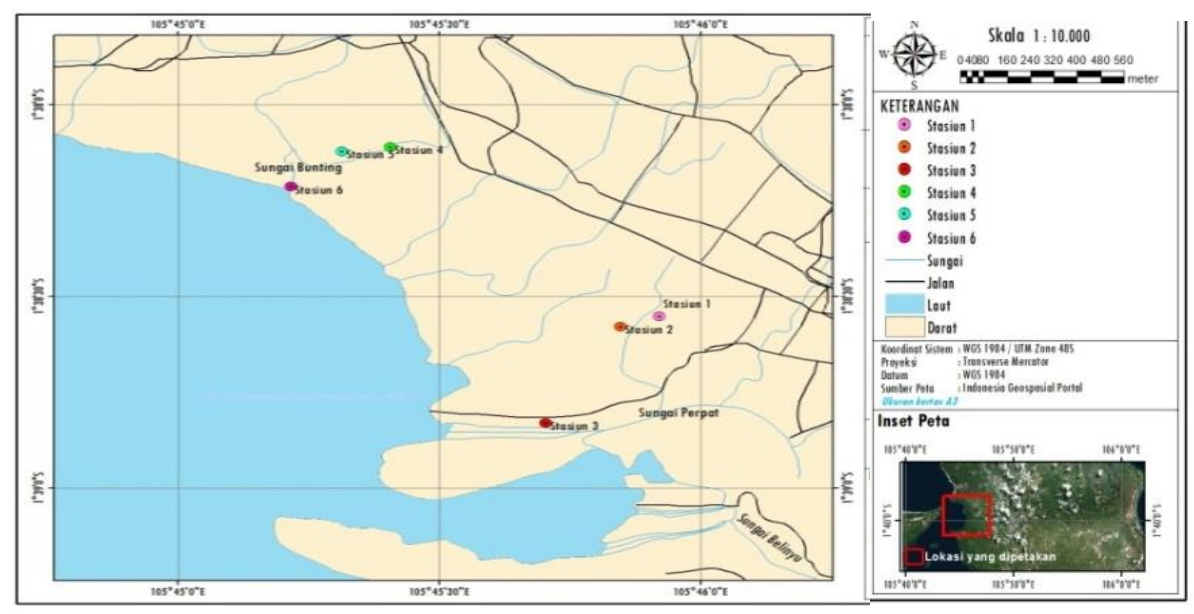

Gambar 1. Peta Lokasi Penelitian 
Kepadatan bivalvia ditentukan berdasarkan data jumlah individu yang ditemukan di setiap kuadrat, kemudian dihitung menggunakan rumus (Krebs 1978). Keanekaragaman spesies ditentukan menggunakan rumus indeks diversitas Shanon (Krebs 1978). Kemudian hasil perhitungan indeks keanekaragaman dikategorikan yaitu rendah $\left(H^{\prime}<1\right)$, sedang $\left(H^{\prime} 1 \leq H^{\prime} \leq 3\right)$ dan tinggi $\left(H^{\prime} \geq 3\right)$. Indeks keseragaman dihitung menggunakan rumus indeks keseragaman (Brower et al., 1998). Indeks dominansi dihitung menggunakan rumus (Brower et al., 1998).

Analisis vegetasi mangrove dilakukan dengan menghitung kerapatan dan Indeks Nilai Penting (INP) dengan bantuan Microsoft office excel 2010. Penentuan tipe substrat dilakukan dengan menghitung fraksi pasir, debu dan liat kemudian dicocokkan dengan segitiga tekstur. Analisis hubungan mangrove, parameter lingkungan dengan kepadatan bivalvia menggunakan software Statistica 6 dengan dilakukan uji yaitu Principal Component Analysis (PCA). Data yang digunakan dalam analisis ini yaitu data mangrove, data lingkungan (suhu air, $\mathrm{pH}$ air, DO dan salinitas) yang dibandingkan dengan data kepadatan bivalvia.

\section{HASIL DAN PEMBAHASAN}

Semua bivalvia yang ditemukan berhasil diidentifikasi. Bivalvia di kawasan Mangrove Perpat sebanyak 183 individu terdiri dari sembilan famili dan dua belas spesies dan Kawasan Bunting diperoleh sebanyak 82 individu terdiri dari enam famili dan tujuh spesies. Spesies bivalvia tertinggi yaitu Geloina exspansa sebanyak 70 individu sedangkan spesies terendah yaitu Anomalodiscus squamosus sebanyak 1 individu. Berdasarkan hasil spesies bivalvia paling banyak ditemukan pada kawasan mangrove Perpat sedangkan spesies mangrove paling banyak ditemukan pada kawasan Bunting. Sedikitnya spesies bivalvia yang ditemukan pada mangrove Bunting diduga karena beberapa hal seperti faktor lingkungan, keberadaan jenis mangrove dan lainnya. Hal ini sejalan dengan Agustini et al. (2016) yang menyatakan bahwa perbedaan jenis vegetasi mangrove merupakan salah satu faktor yang berpengaruh terhadap kelimpahan kerang di dalamnya. Sejalan dengan pernyataan Aida et al. (2014), bahwa mangrove tingkat pohon memiliki produksi serasah tertinggi dibanding semai dan pancang. Jenis mangrove yang mendominasi di kawasan Perpat adalah Rhizophora apiculata sedangkan pada kawasan mangrove Bunting adalah Xylocarpus granatum dan Sonneratia alba. Secara keseluruhan bivalvia yang paling banyak ditemukan pada penelitian ini adalah Geloina expansa sedangkan Anomalodiscus squamosus paling sedikit.

Berdasarkan hasil jumlah total individu bivalvia tertinggi pada stasiun 1 dibandingkan dengan stasiun lainnya. Jumlah individu tertinggi pada stasiun 1 spesies Lutraria lutraria. Adapun tipe substrat pada stasiun 1 adalah lempung liat berpasir yang mendukung untuk pertumbuhan spesies Lutraria lutraria. Sedangkan jumlah spesies bivalvia tertinggi pada stasiun 3, hal ini diduga karena lokasi pengamatan bersinggungan langsung dengan lautan sehingga diduga nutrisi atau bahan makanan lebih banyak. Lawerissa et al. (2018) juga menyatakan bahwa zonasi yang terdekat dengan laut, akan didominasi oleh Avicennia sp. dan Sonneratia sp. yang tumbuh pada substrat lunak dengan kandungan organik yang tinggi. Salah satu spesies bivalvia yang paling banyak ditemukan pada stasiun 3 adalah Meretrix meretrix. Menurut Indraswari et al. (2014) Meretrix meretrix dapat ditemukan hidup membenamkan diri pada substrat berpasir. Oleh karena itu tipe substrat pada stasiun 3 cocok untuk pertumbuhan spesies ini. Keberadaan bivalvia pada stasiun 6 adalah paling rendah dimana hanya ditemukan dua spesies yaitu Anadara gubernaculum dan Placamen chloroticum. Beberapa hal yang mungkin terjadi seperti perkembangbiakan bivalvia yang tidak mendukung, contohnya pada saat masih dalam fase juvenil bivalvia mati dikarenakan aktifitas penambangan timah, selain itu diduga terdapat kandungan logam berat dari aktifitas penambangan yang menyebabkan pengecilan gonad sehingga menghambat pertumbuhan bivalvia (Indraswari et al., 2014).

Spesies bivalvia yang didapat pada penelitian ini namun belum pernah ditemukan pada beberapa penelitian bivalvia di wilayah 
pesisir di Bangka Belitung yaitu Cochlodesma praetenue (kerang lentera dapat dijumpai meliang di bawah sedimen atau substrat pada zona intertidal suatu perairan. Menurut Ambarwati et al. (2019) kerang lentera merupakan anggota invertebrata purba. Suharsono (2014) juga menyatakan bahwa persebaran kerang lentera ini terbatas hanya di sebagian wilayah Indonesia saja. Beberapa spesies bivalvia yang ditemukan dapat dilihat pada Gambar 1 sedangkan nilai hasil perhitungan indeks kepadatan bivalvia dapat dilihat pada Tabel 1.

Kepadatan bivalvia tertinggi pada stasiun 1 dan terendah pada stasiun 6 . Kepadatan bivalvia tertinggi pada penelitian ini adalah spesies Geloina exspansa. Hal ini berbeda dengan Penelitian yang dilakukan oleh Akhrianti et al. (2014) mengenai Distribusi Spasial dan Preferensi Habitat Bivalvia di Pesisir Perairan Kecamatan Simpang Pesak Kabupaten Belitung Timur dimana spesies bivalvia dengan kepadatan tertinggi yaitu Gafrarium pectinatum, Gafrarium tumidum dan Scapharca pilula. Nilai kerapatan mangrove pada kawasan Sungai Perpat lebih kecil dibandingkan pada kawasan Sungai Bunting, namun bivalvia yang didapatkan pada kawasan mangrove Sungai Perpat lebih banyak. Oleh karena itu jika kerapatan mangrove tinggi maka keberadaan bivalvia di dalamnya juga tinggi. Namun hasil yang didapatkan pada penelitian yang dilakukan bivalvia banyak ditemukan pada kondisi kerapatan mangrove yang rendah. Walaupun demikian kerapatan mangrove sangat berpengaruh terhadap kepadatan bivalvia di dalamnya karena mangrove merupakan salah satu penyedia bahan organik untuk kelangsungan hidup bivalvia. Adapun faktor penyebab terjadinya hal tersebut dimana pengaruh kerapatan mangrove tertutupi oleh faktor lain. Menurut Samir dan Romy, (2016) tolak ukur tersebut misalnya ketersediaan makanan dan kondisi parameter lingkungan yang terjadi setiap harinya. Kondisi parameter lingkungan setiap harinya pasti memiliki perbedaan dimana kondisi iklim dan cuaca sangat mempengaruhi.

Perbedaan nilai kepadatan bivalvia pada setiap stasiun juga disebabkan adanya faktor lain seperti penangkapan bivalvia yang tidak selektif oleh masyarakat sekitar. Hal ini terlihat pada saat penelitian berlangsung dimana masyarakat banyak menangkap dan memanfaatkan bivalvia baik untuk konsumsi sendiri maupun untuk dijual. Spesies bivalvia yang paling banyak ditangkap adalah Geloina expansa dan Meretrix meretrix. Hal ini juga terlihat pada sedikitnya bivalvia yang didapat dengan ukuran besar, yakni hanya beberapa spesies Geloina expansa dengan ukuran panjang cangkang $6,31 \mathrm{~cm}$, spesies Lithophaga teres dengan panjang cangkang $6,8 \mathrm{~cm}$ dan Pharella javanica dengan panjang cangkang $7,45 \mathrm{~cm}$. Berdasarkan hasil penelitian terlihat bahwa bivalvia berukuran sedang $(3-5,25 \mathrm{~cm})$ merupakan ukuran yang paling dominan sehingga dapat dikatakan bahwa bivalvia yang banyak ditemukan adalah bivalvia muda. Hal ini sejalan dengan Wanimbo dan John (2018) bahwa ukuran bivalvia $5,7 \mathrm{~cm}$ sampai $7,8 \mathrm{~cm}$ dikategorikan bivalvia dewasa. Bivalvia mampu tumbuh mencapai ukuran 4,89 cm - 16,5 cm (Gosling 2004). Hasil pengukuran morfometri cangkang bivalvia dapat dilihat pada Tabel 2.

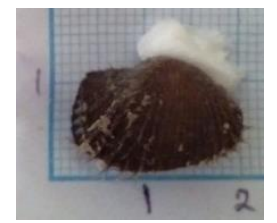

Anadara gubernaculum

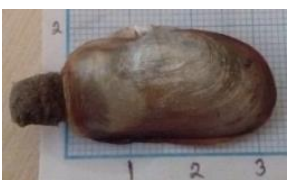

Cochlodesma praetenue

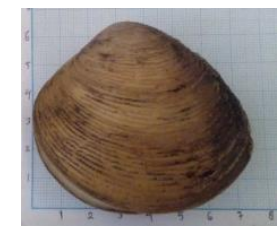

Geloina exspansa

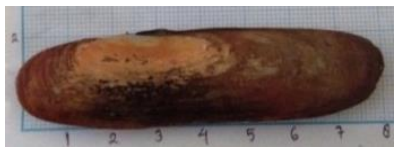

Pharella javanica

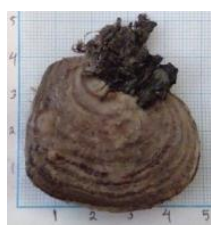

Isognomon alatus

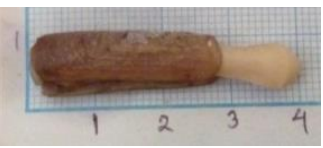

Solen sicarius

Gambar 1. Beberapa jenis-jenis Bivalvia yang ditemukan 
Tabel 1. Nilai Kepadatan (Ind/m²) Bivalvia pada Masing-masing Stasiun Penelitian

\begin{tabular}{|c|c|c|c|c|c|c|c|}
\hline \multirow{2}{*}{ No } & \multirow{2}{*}{ Spesies } & \multicolumn{6}{|c|}{ Kepadatan (Ind/m²) } \\
\hline & & St 1 & $S+2$ & St 3 & St 4 & St 5 & St 6 \\
\hline 1 & Anadara gubernaculum & - & - & 0,1 & - & - & 0,15 \\
\hline 2 & Anomalodiscus squamosus & - & - & 0,05 & - & - & - \\
\hline 3 & Cochlodesma praetenue & - & - & 0,15 & - & - & - \\
\hline 4 & Geloina expansa & 1,15 & 1,25 & - & 1,1 & - & - \\
\hline 5 & Isognomon alatus & - & - & 0,1 & - & 0,55 & - \\
\hline 6 & Lithopaga teres & 0,95 & 0,2 & 0,65 & - & 0,25 & - \\
\hline 7 & Lutraria lutraria & 1,55 & - & - & - & - & - \\
\hline 8 & Mactra grandis & - & - & 0,4 & - & - & - \\
\hline 9 & Meretrix meretrix & - & - & 1,55 & - & - & - \\
\hline 10 & Pharella javanica & 0,5 & 0,1 & - & - & 1,05 & - \\
\hline 11 & Placamen chloroticum & - & - & 0,15 & - & - & 0,25 \\
\hline 12 & Solen sicarius & - & - & 0,3 & - & - & - \\
\hline & Total & 4,15 & 1,55 & 3,45 & 1,1 & 1,85 & 0,4 \\
\hline
\end{tabular}

Ket: Stasiun 1, 2 dan 3 (Kawasan Mangrove Perpat), Stasiun 4, 5 dan 6 (Kawasan Mangrove Bunting)

Tabel 2. Hasil Pengukuran Morfometri Cangkang Bivalvia

\begin{tabular}{|c|c|c|c|c|c|c|c|}
\hline \multirow[t]{2}{*}{ No } & \multirow[t]{2}{*}{ Spesies } & \multicolumn{2}{|c|}{ Rata-rata $(\mathrm{cm}) \mathrm{SD}$} & \multirow[t]{2}{*}{ No } & \multirow[t]{2}{*}{ Spesies } & \multicolumn{2}{|c|}{ Rata-rata $(\mathrm{cm}) \mathrm{SD}$} \\
\hline & & Panjang & Lebar & & & Panjang & Lebar \\
\hline 1 & $\begin{array}{l}\text { Anadara } \\
\text { gubernaculum }\end{array}$ & $0,71 \pm 2$ & $0,42 \pm 1,3$ & 7 & $\begin{array}{l}\text { Lutraria } \\
\text { lutraria }\end{array}$ & $1,63 \pm 4,35$ & $0,35 \pm 2,45$ \\
\hline 2 & $\begin{array}{l}\text { Anomalodiscus } \\
\text { squamosus }\end{array}$ & 1,6 & 1,1 & 8 & $\begin{array}{l}\text { Mactra } \\
\text { grandis }\end{array}$ & $1,10 \pm 2,85$ & $1,06 \pm 2,55$ \\
\hline 3 & $\begin{array}{l}\text { Cochlodesma } \\
\text { praetenue }\end{array}$ & $2,62 \pm 3,25$ & $0,85 \pm 1,5$ & 9 & $\begin{array}{l}\text { Meretrix } \\
\text { meretrix }\end{array}$ & $2,47 \pm 5,25$ & $1,98 \pm 4,2$ \\
\hline 4 & $\begin{array}{l}\text { Geloina } \\
\text { expansa }\end{array}$ & $5,66 \pm 6,31$ & $5,10 \pm 6,26$ & 10 & $\begin{array}{l}\text { Pharella } \\
\text { javanica }\end{array}$ & $0,21 \pm 7,45$ & $0,21 \pm 1,85$ \\
\hline 5 & $\begin{array}{l}\text { Isognomon } \\
\text { alatus }\end{array}$ & $1,70 \pm 3$ & $1,63 \pm 3,35$ & 11 & $\begin{array}{l}\text { Placamen } \\
\text { chloroticum }\end{array}$ & $0,14 \pm 2,3$ & $0,21 \pm 2,15$ \\
\hline 6 & $\begin{array}{l}\text { Lithophaga } \\
\text { teres }\end{array}$ & $1,13 \pm 6,8$ & $0,35 \pm 1,75$ & 12 & $\begin{array}{l}\text { Solen } \\
\text { sicarius }\end{array}$ & $0,42 \pm 2,7$ & $0,21 \pm 0,75$ \\
\hline
\end{tabular}

Keanekaragaman bivalvia pada kawasan mangrove Bunting di kategorikan rendah berdasarakan kriteria Shannon-Wiener dan diartikan bahwa komunitas bivalvia di Kawasan mangrove Bunting dalam kondisi lingkungan yang tercemar berat. Hal tersebut dapat dilihat dari nilai H'bivalvianya yaitu 0 0,95. Menurut Wilhm dan Dorris (1966) tentang tingkat pencemaran, indeks keanekaragaman 0 - 1,0 dengan tingkat pencemaran tercemar berat. Nilai indeks keseragaman bivalvia pada masing-masing lokasi berbeda. Hal ini dapat dilihat pada nilai indeks keseragaman pada stasiun 1, 2, 4, 5 dan 6 dimana $\mathrm{E}$ mendekati 0 yang menunjukkan bahwa sebaran individu antar jenis tidak merata/ada da stasiun 3 nilai E mendekati 1 yang menunjukkan bahwa sebaran individu antar jenis merata. Nilai indeks keseragaman tertinggi terdapat pada stasiun 3 sehingga hal ini menunjukkan pada stasiun 3 terjadi keseimbangan ekologis pada suatu komunitas, di mana semakin tinggi nilai keseragaman kualitas lingkungan semakin baik dan cocok dengan kehidupan bivalvia. Hasil perhitungan nilai indeks keanekaragaman, keseragaman dan dominansi bivalvia (Tabel 3).

Sebanyak tujuh spesies mangrove yang dijumpai pada kawasan Perpat yaitu Bruguiera gymnorrhiza, Bruguiera cylindrica, 
Rhizophora apiculata, Excoecaria agallocha, Derris trifoliata, Xylocarpus granatum dan Aviccenia alba. Sebanyak sembilan spesies mangrove pada kawasan Bunting yaitu Bruguiera gymnorrhiza, Bruguiera cylindrica, Rhizophora apiculata, Rhizophora mucronata, Excoecaria agallocha, Derris trifoliata, Xylocarpus granatum, Sonneratia alba dan Scyphiphora hydrophyllaceae. Stasiun pengamatan dengan kerapatan mangrove tertinggi untuk kategori semai terdapat pada stasiun 4 dengan kerapatan 1300 tegakan/ha dan termasuk kriteria sedang. Stasiun 1, 2, 3, 5 dan 6 termasuk dalam kriteria kerapatan jarang untuk kategori semai. Kerapatan mangrove tertinggi untuk kategori pancang pada stasiun 5 dengan kerapatan 800 tegakan/ha dan keenam stasiun termasuk dalam kriteria kerapatan jarang untuk kategori pancang. Kerapatan mangrove tertinggi untuk kategori pohon pada stasiun 5 dengan kerapatan 1900 tegakan/ha dan termasuk kriteria padat. Stasiun 1, 2 dan 3 termasuk dalam kriteria kerapatan jarang, stasiun 4 dan 6 termasuk dalam kriteria sedang berdasarkan KepMen LH Nomor 201 Tahun 2004.
Kisaran Indeks Nilai Penting tingkat pancang pada lokasi penelitian adalah berkisar 33,36-300. Spesies Rhizophora apiculata pada stasiun 2 dan Rhizophora mucronata pada stasiun 6 memiliki INP tertinggi yaitu masingmasing sebesar 300 sedangkan untuk INP terendah adalah jenis Scyphiphora hydrophyllaceae pada stasiun 4. Kisaran Indeks Nilai Penting tingkat pohon pada lokasi penelitian adalah 12,3-269,96. Spesies Rhizophora mucronata pada stasiun 6 memiliki INP tertinggi yaitu 238,63 sedangkan untuk INP terendah adalah jenis Bruguiera cylindrica pada stasiun 5. Adapun hasil pengukuran parameter lingkungan dan tipe substrat dapat dilihat pada Tabel 5. Adapun hasil pengukuran parameter lingkungan dan tipe substrat dapat dilihat pada Tabel 4.

Analisa beberapa variabel lingkungan yang dimasukkan dalam analisis komponen utama (Principal Component Analysis) meliputi suhu air, salinitas, $\mathrm{pH}$ air, DO, kerapatan mangrove dan kepadatan bivalvia dapat dilihat pada Gambar 2.

Tabel 3. Nilai Indeks Keanekaragaman (H'), Indeks Keseragaman(E) dan Dominansi (C)

\begin{tabular}{ccccc}
\hline No & Stasiun & $\mathrm{H}^{\prime}$ & $\mathrm{E}$ & $\mathrm{C}$ \\
\hline 1 & $\mathrm{I}$ & 1,315 & 0,445 & 0,283 \\
2 & $\mathrm{II}$ & 0,614 & 0,499 & 0,671 \\
3 & $\mathrm{III}$ & 1,675 & 1,010 & 0,264 \\
4 & $\mathrm{IV}$ & 0 & 0 & 1 \\
5 & $\mathrm{~V}$ & 0,952 & 0,424 & 0,428 \\
6 & $\mathrm{VI}$ & 0,661 & 0,517 & 0,531
\end{tabular}

Keterangan : Stasiun 1, 2 dan 3 (Kawasan Sungai Perpat), Stasiun 4, 5 dan 6 (Kawasan Sungai Bunting)

Tabel 4. Hasil Pengukuran Parameter Lingkungan dan Tipe Substrat

\begin{tabular}{|c|c|c|c|c|c|c|c|}
\hline Parameter & $\begin{array}{c}\text { Stasiun } \\
1\end{array}$ & $\begin{array}{c}\text { Stasiun } \\
2 \\
\end{array}$ & $\begin{array}{c}\text { Stasiun } \\
3 \\
\end{array}$ & $\begin{array}{c}\text { Stasiun } \\
4 \\
\end{array}$ & $\begin{array}{c}\text { Stasiun } \\
5 \\
\end{array}$ & $\begin{array}{c}\text { Stasiun } \\
6\end{array}$ & $\begin{array}{c}\text { Rata-rata } \\
\text { (SD) }\end{array}$ \\
\hline Suhu air $\left({ }^{\circ} \mathrm{C}\right)$ & 31 & 28 & 32 & 31 & 29 & 32 & $31 \pm 1,64$ \\
\hline Salinitas (ppt) & 22 & 31 & 32 & 30 & 33 & 35 & $31 \pm 4,51$ \\
\hline pH air & 7,18 & 7,01 & 7,32 & 7,01 & 7,20 & 7,21 & $7,2 \pm 0,12$ \\
\hline DO (mg/l) & 4,51 & 4,62 & 4,70 & 4,59 & 4,52 & 4,54 & $4,6 \pm 0,07$ \\
\hline Substrat & $\begin{array}{c}\text { Lempung } \\
\text { liat } \\
\text { berpasir }\end{array}$ & $\begin{array}{c}\text { Lempung } \\
\text { liat } \\
\text { berpasir }\end{array}$ & Pasir & $\begin{array}{l}\text { Lempung } \\
\text { berpasir }\end{array}$ & $\begin{array}{c}\text { Pasir } \\
\text { berlempung }\end{array}$ & $\begin{array}{c}\text { Pasir } \\
\text { berlempung }\end{array}$ & \\
\hline
\end{tabular}

Keterangan: Stasiun 1, 2 dan 3 (Kawasan Mangrove Perpat), Stasiun 4, 5 dan 6 (Kawasan Mangrove Bunting). 

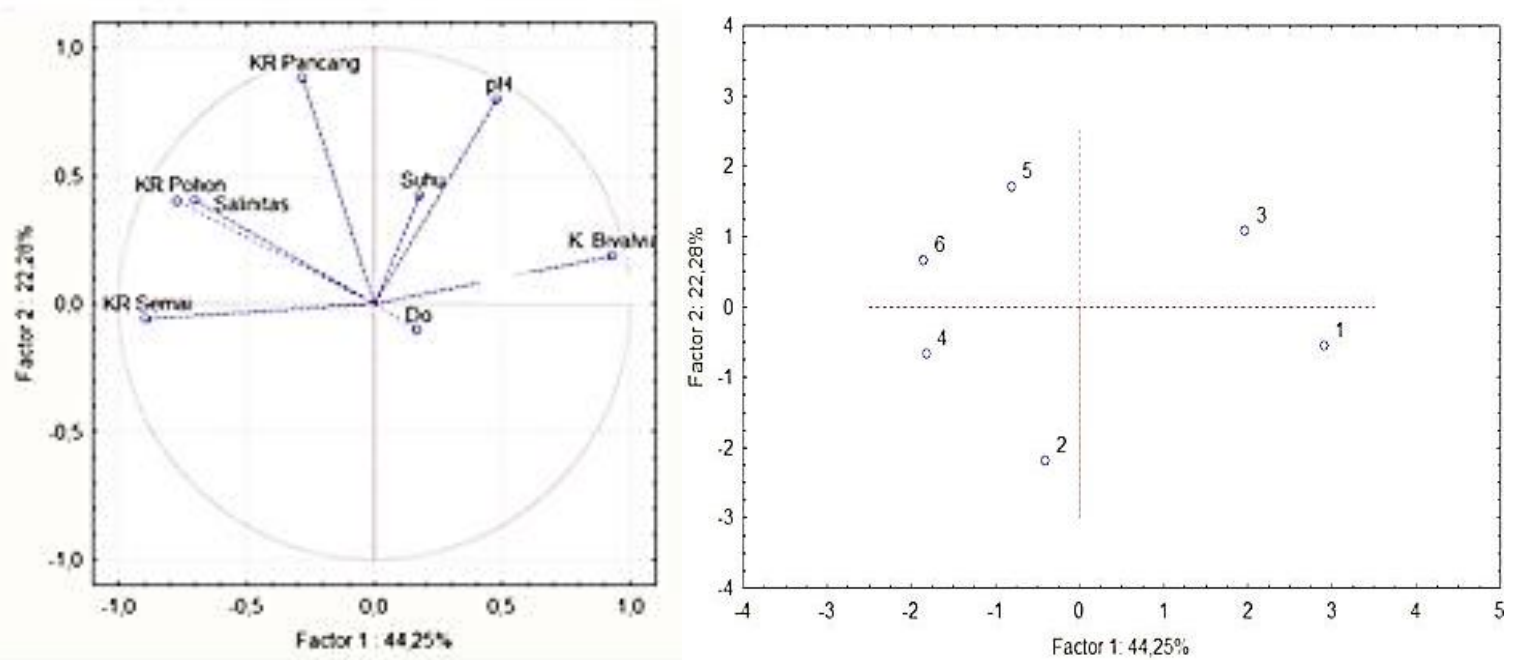

Gambar 2. Hasil Analisis Komponen Utama

Berdasarkan hasil analisis diketahui bahwa terdapat korelasi positif antara suhu air dengan $\mathrm{pH}$ air. Selain itu diketahui terdapat korelasi positif antara salinitas dengan kerapatan mangrove kategori pohon, mangrove kategori pancang dan mangrove kategori semai. Korelasi positif juga terdapat pada parameter $\mathrm{pH}$ dengan kepadatan bivalvia. Terdapat korelasi negatif antar variabel yaitu pada suhu dengan salinitas. Korelasi negatif lainnya yaitu pada salinitas dengan kepadatan bivalvia. Faktor lingkungan yang paling mempengaruhi kepadatan bivalvia pada penelitian ini adalah $\mathrm{pH}$ air dan suhu air. Kadar $\mathrm{pH}$ dalam perairan merupakan parameter lingkungan yang berpengaruh terhadap kehidupan organisme. Semakin tinggi derajat keasaman makan akan semakin mendukung organisme pengurai untuk menguraikan bahan-bahan organik yang jatuh pada mangrove. Suhu air mempengaruhi secara langsung aktifitas organisme seperti pertumbuhan dan metabolisme bahkan menyebabkan kematian terhadap organisme. Sedangkan pengaruh tidak langsung meningkatkan daya akumulasi berbagai zat kimia dan menurunkan kadar oksigen dalam air. Suhu juga merupakan merupakan faktor bagi beberapa hewan biologis air seperti migrasi, pemijahan, kecepatan proses pekembangan embrio, seta kecepatan begerak. Hasil analisis PCA menunjukkan bahwa terdapat korelasi positif antara salinitas dengan kerapatan mangrove. Hal ini dikarenakan salinitas merupakan faktor lingkungan yang sangat menentukan perkembangan hutan mangrove, terutama bagi laju pertumbuhan, daya tahan dan zonasi spesies mangrove. Selain salinitas suhu juga mempengaruhi kerapatan mangrove dimana suhu merupakan faktor penting dalam proses fisiologi seperti fotosintesis dan respirasi.

Hubungan antara kerapatan jenis mangrove terhadap keberadaan bivalvia pada penelitian ini menunjukkan hubungan sangat lemah karena berdasarkan hasil yang didapatkan keberadaan bivalvia tertinggi pada lokasi dengan kerapatan mangrove yang rendah. Meskipun demikian kerapatan mangrove sangat berpengaruh terhadap keberadaan bivalvia karena mangrove dapat menyediakan bahan organik melalui fotosintesis. Hubungan antara kerapatan mangrove dengan kepadatan bivalvia pada penelitian ini berkorelasi negatif, namun tetap didukung oleh faktor lainnya seperti parameter lingkungan dan ketersediaan makanan bagi kelangsungan hidup bivalvia.

Hasil analisis komponen utama menunjukkan bahwa keenam stasiun memiliki karakteristik yang berbeda dan faktor fisikkimia perairan yang mempengaruhi keberadaan bivalvia. Stasiun 1 dicirikan dengan DO terendah, rendahnya DO diduga disebabkan oleh beberapa faktor seperti kondisi mangrove yang tertutup dan kehadiran lumpur yang dihasilkan setelah 
terjadi hujan. Hal ini sejalan dengan pernyataan (Borja et al., 2000) bahwa rendahnya nilai DO disebabkan oleh kandungan lumpur pada substrat dasar perairan yang mengakibatkan partikel terlarut dan tersuspensi dalam kolom air sehingga dapat menyebabkan rendahnya kadar oksigen. Namun moluska masih dapat bertahan hidup karena mereka mampu beradaptasi pada kandungan oksigen yang rendah dimana mereka akan menutup cangkang dan melakukan respirasi anaerob. Stasiun 2 dan 4 dicirikan dengan kerapatan mangrove kategori semai. Stasiun 3 dicirikan dengan $\mathrm{pH}$ air dan suhu air, stasiun 5 dan 6 dicirikan dengan salinitas.

Berdasarkan hasil tersebut dapat dikatakan bahwa stasiun 2 memiliki kemiripan dengan stasiun 4 , stasiun 5 memiliki kemiripan dengan stasiun 6. Sedangkan stasiun 1 dan 3 tidak memiliki kemiripan. Tingginya $\mathrm{pH}$ air dan suhu air pada stasiun 3 diduga disebabkan oleh kondisi kawasan mangrove yang berbatasan langsung dengan laut. Nilai pH air dan suhu air pada stasiun 3 diduga sangat mendukung untuk pertumbuhan bivalvia sehingga jumlah spesies bivalvia yang ditemukan lebih tinggi dibandingkan kelima stasiun lainnya. Adapun hasil pengukuran parameter fisik dan kimia diantaranya nilai suhu berkisar 28-32, nilai ini masih dala kisaran normal untuk kehidupan bivalvia. Hal ini sesuai dengan KepMen LH Nomor 51 Tahun 2004 tentang Baku Mutu Air dengan suhu $28-32^{\circ} \mathrm{C}$ untuk ekosistem mangrove (Zahroh et al., 2019). Nilai salinitas juga masih berada dalam kisaran normal yaitu 22-35 ppt. Menurut Guntur (2011) salinitas yang berkisar antara 32-35 ppt merupakan salinitas yang optimal bagi kerang untuk hidup secara normal. Nilai $\mathrm{pH}$ berkisar antara 7,01-7,32, nilai ini masih berada dalam kisaran normal. Hal ini sesuai dengan pernyataan Akbar et al. (2014) yang menyatakan bahwa nilai $\mathrm{pH}$ yang berkisar antara 7-8,5 merupakan nilai yang baik untuk pertumbuhan molusca, krustase, dan mangrove. Nilai DO juga masih berada dalam kisaran normal antara 4,51-4,70 mg/l. hal ini sesuai dengan Kisman et al. (2016) bahwa kerang menyukai lingkungan dengan kandungan oksigen terlarut antara 3,8-12,5 $\mathrm{mg} / \mathrm{l}$.

\section{KESIMPULAN}

Jumlah bivalvia yang ditemukan di kawasan mangrove Perpat sebanyak 183 individu terdiri dari sembilan famili dan dua belas spesies sedangkan pada kawasan mangrove Bunting diperoleh sebanyak 82 individu terdiri dari enam famili dan tujuh spesies. Indeks kepadatan (D) bivalvia pada kawasan mangrove Perpat dengan kisaran nilai 1,55-4,15 ind $/ \mathrm{m}^{2}$ lebih tinggi dibandingkan dengan kawasan mangrove Bunting. Kerapatan mangrove tertinggi pada kawasan mangrove Bunting dengan kisaran nilai kerapatan 500-1300 tegakan /ha. Hasil analisis PCA menunjukkan bahwa kepadatan bivalvia pada penelitian ini lebih dipengaruhi oleh suhu air dan $\mathrm{pH}$ air. Sedangkan hubungan antara kerapatan jenis mangrove terhadap kepadatan bivalvia pada penelitian ini menunjukkan hubungan sangat lemah, namun tetap didukung oleh faktor lainnya seperti parameter lingkungan, ketersediaan makanan bagi kelangsungan hidup bivalvia.

\section{DAFTAR PUSTAKA}

Abbott, R.T. \& Dance, S.P., 2000, Compedium of Seashells, Odyssey Publishing, Cina.

Agustini, N.T., Dietriech, G. \& Tri, P. 2016. Asosiasi Kerang Lokan Geloina Erosa Solander 1786 dan Mangrove di di Kawasan Pesisir Kahyapu Pulau Enggano, Provinsi Bengkulu. Jurnal Ilmu dan Teknologi Kelautan Tropis, 8(2):613-624.

Aida, G.R., Yusli, W., Achmad, F. \& Mohammad, M.K. 2014. Produksi Serasah Mangrove di Pesisir Tangerang, Banten. Jurnal IImu Pertanian Indonesia, 19(2):9197.

Akbar, J., Bahtiar, B. \& Ishak, E. 2014. Studi Morfometrik Kerang Kalandue (Polymesoda erosa) di Hutan Mangrove Teluk Kendari. Jurnal Mina Laut Indonesia, 4(1):1-12.

Akhrianti, I., Dietriech, G.B. \& Isdradjad, S. 2014. Distribusi Spasial dan Preferensi Habitat Bivalvia di Pesisir Perairan Kecamatan Simpang Pesak Kabupaten Belitung Timur. Jurnal Ilmu dan Teknologi Kelautan Tropis, 6(1):171-185

Ambarwati, R., Rahayu, D.A. \& Faizah, U. 2019. The Potency and Food Safety of Lamp Shells (Brachiopoda: Lingula sp.) as Food Resources. J. Phys: Conf. Ser, 1417:12039. doi: 10.1088/17426596.2019.01.012. 
Borja, A.J., Franco \& Perez, V. 2000. A marine biotic index to estabilish the ecological quality of soft-bottom benthos within European estuarine and coastal environments, Marine Pollution Bulletin: $1100-1114$.

Brower, J.E., Zar, J.H. \& Von Ende, C.N., 1998. Field and Laboratory Methods for General Zoology. Third edition. United States of America. America: W.M.C Brown Publisher.

Chandra, I.A., Seca, G. \& Hena, M.A. 2011. Aboveground Biomass Production of Rhizophora apiculata Blume in Sarawak Mangrove Forest. Agricultural and Biological Sciences, 6(4):469-474. doi: 10.3844/ajabssp.2011.469.474

Dewiyanti, I \& Sofyatuddin, K. 2011 . Diversity of Gastropods and Bivalves in Mangrove Ecosystem Rehabilitation Areas in Aceh Besar and Banda Aceh Districts, Indonesia. AACL Bioflux, 5(2):55-59.

Dharma, B., 2005, Siput dan Kerang Indonesia (Indonesian Shells II), PT. Sarana Graha, Jakarta.

Gosling, E. 2004. Bivalvia Mollusc Biology, Ecology and Culture. Fishing Bews Book $327 \mathrm{pp}$.

Guntur. 2011. Ekologi Karang pada Terumbu Buatan. Bogor: Ghalia Indonesia.

Indraswari, A.G.M., Litaay, M. \& Soekendarsi, E. 2014. Morfometri Kerang Tahu Meretrix meretrix Linnaeus, 1758 di Pasar Rakyat Makassar. Berita Biologi, 13(2):137-142.

Kisman, M.D., Achmad, R. \& Muchlis, D. 2016. Jenis Jenis dan Keanekaragaman Bivalvia di Perairan Laut Pulau Maputi Kecamatan Sojol Kabupaten Donggala dan Pemanfaatannya Sebagai Media Pembelajaran Biologi. e-Jipbiol, 4(1):1-14.

Lawerissa, Y.A., Sangaji, M. \& Latumahina, M.B. 2018. Pengelolaan Mangrove Berdasarkan Tipe Substrat di Perairan Negeri Ihamahu Pulau Saparua. Jurnal Triton, 14(1):1-9.

Mughofar, A., Mohammad, M. \& Prabang, S. 2018. Zonasi dan Komposisi Vegetasi Hutan Mangrove Pantai Cengkrong Desa Karanggandu Kabupaten Trenggalek Provinsi Jawa Timur. Jurnal Pengelolaan Sumberdaya Alam Dan Lingkungan, 8(1):77-85. doi: 10.29244/jpsl.8.1.77-85

Natsir, N.A. \& Asyik, N.A.A.F., 2019, Analisis Frekuensi dan Keragaman Bivalvia di
Perairan Pantai Pulau Ay Kecamatan Banda Kabupaten Maluku Tengah, Prosiding Seminar Nasional Kelautan dan Perikanan Fakultas Perikanan dan IImu Kelautan Unpatti, Ambon: 18-19 Desember 2019.

Noor, Y.R., Muhammad, K. \& Suryadiputra, I.N.N. 2006. Panduan Pengenalan Mangrove di Indonesia, PHKA/WI-IP, Bogor.

Pakaya, F., Abd, H.O. \& Citra, P. 2017. Keanekaragaman dan Kelimpahan Bivalvia Pada Ekosistem Mangrove di Desa Mananggu Kecamatan Mananggu Kabupaten Boalemo. Jurnal IImiah Perikanan dan Kelautan, 5(1):31-34.

Samir, W.N. \& Romy, K. 2016. Studi Kepadatan dan Pola Distribusi Bivalvia di Kawasan Mangrove Desa Balimu Kecamatan Lasalimu Selatan Kabupaten Buton. Jurnal Manajemen Sumber Daya Perairan, No.2, Vol.1, 169-181.

Suharsono., 2014, Biodiversitas Biota Laut Indonesia, Pusat Penelitian OseanografiLIPI, Jakarta.

Triwiyanto, K., In, M.S. \& Job, N.S. 2015. Keanekaragaman Moluska di Pantai Serangan, Desa Serangan, Kecamatan Denpasar Selatan, Bali. Jurnal Biologi, $19(2): 63-68$.

Wanimbo, E., 2016, Pola Pertumbuhan Respon Osmotik dan Tingkat Kematangan Gonad Kerang Polymesoda erosa di Perairan Teluk Youtefa Jayapura Papua. Prosiding Seminar Hasil-hasil Perikanan dan Kelautan ke VI, Fakultas Perikanan dan Ilmu Kelautan-Pusat Mitigasi Bencana dan Rehabilitasi Pesisir, Universitas Diponegoro, Semarang.

Wahyuni, I., Indah, J.S. \& Bambang, E. 2017. Biodiversitas Mollusca (Gastropoda dan Bivalvia) sebagai Bioindikator Kualitas Perairan di Kawasan Pesisir Pulau Tunda, Banten. Jurnal Biodidaktika, 12(2):45-56.

Wilhm, J.L. \& Dorris, T.C. 1966. Biological Parameter for Water Quality Criteria, Biology Scientific Publication, Oxford.

Zahroh, A., Etti, R. \& Syaiful, A. 2019. Analisis Kualitas Perairan untuk Budidaa Kerang Hijau di Kabupaten Cirebon Provinsi Jawa Barat. Jurnal Pengelolaan Sumberdaya Alam dan Lingkungan, 9(1):86-91. doi: 10.29244/jpsl.9.1.86-91 